\title{
Hashtag Activism: a Thematic Analysis of Online Social Movement inIndonesia
}

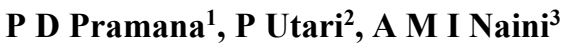 \\ ${ }^{1}$ Master's Degree of Communication, Faculty of Social and Political Science, Sebelas Maret University, \\ Surakarta, Indonesia, ${ }^{2,3}$ Department of Communication, Faculty of Social and Political Science, Sebelas \\ Maret University, Surakarta, Indonesia \\ 1'pinandito.dp@student.uns.ac.id,2prahastiwi@staff.uns.ac.id, ${ }^{3}$ albert_muhammad@staff.uns.ac.id
}

\begin{abstract}
This study aimed to determine the use and theme of hashtags used by online activists in Indonesia through big data approach. The object of the research was the Wamena riot and demonstrations by the students against the bill which occurred simultaneously in the end of September 2019. This study was a quantitative and qualitative content analysis from social media Twitter. Quantitative analysis was performed by retrieving the results of big data processing by an online platform called Drone Emprit Academic to find out the ten most frequently used hashtags by activists. Qualitative analysis was then performed by using thematic analysis from Xiong, Cho and Boatwright. The results of the study of 882,088 tweets indicated that there were differences in the use and theme of the hashtag for the two phenomena that occurred. Wamena riot activists used the theme of advocating for certain actions as the main issue in the use of hashtags, while student activists in protests over the bill gave priority on the activist's role as the main theme.
\end{abstract}

Keywords: hashtag activism, Indonesia, thematic analysis, Twitter

\section{Introduction}

Indonesia experienced two major phenomena that occurred at the same time on September 23, 2019, namely the riots in Wamena and student demonstrations demanding the cancellation of several draft laws. Riots that occurred in Wamena, Papua caused 32 deaths and 67 injuries wound[1]. The riots were allegedly caused by a misunderstanding between a teacher who harassed his students with racial words[2]. On the same day, there were student protests in several cities in Indonesia, and continued until the next day. Students asked The House of Representatives of the Republic of Indonesia (DPR) not to approve the bill[3]. These two events were highlighted in various media including social media, especially Twitter. It was noted that \#HidupMahasiswa (\#GoStudents) to be a worldwide trending topic on that time.

Activists use Twitter in its ability as social media to fulfill a number of things, (1) facilitating protests through advertisements and solicitation of donations, (2) reporting directly on actual protests, (3) forwarding news through links and retweeting, (4) expressing personal opinions about social movements, (5) engaging in discussions about movements, (6) making personal connections with fellow activists and (7) facilitating actions that have a certain basis[4].

Twitter as a digital communication media allows users to voice their ideas and aspirations without geographical restrictions at a much lower cost than traditional media and broadcasting. Protest activists on Twitter were able to upload their tweets geographically far 
from the actual protest position that occurred and users from geographically isolated regions depended on hashtags to remotely engage in action[5].

Hashtags on Twitter have several communication functions in protest actions, different hashtags have different benefits as well as being able to add or change the meaning of a tweet[6]. Online activists use hashtags to demonstrate the use of Twitter as a medium for direct conversation, demonstrations, and disseminating ideas as part of a broader movement on a particular issue. Many social movements have recognized and used hashtags as an effective tool to mobilize the public. Hashtags are also used to analyze the connections of actors, websites, and clusters on different networks[7].

New media theory explain that the internet and affiliated technologies, such as computermediated communication and social media, have special abilities that have changed the way humans exchange their messages. The use of personal computers, tablets and mobile phones plays an important role in this change. The concept emphasizes the use of media from seeking information and knowledge for personal consumption, to becoming an interaction. Through the perspective of social interaction, new media is more interactive media and forms a new meaning of personal communication[8].

Social media users have the freedom to produce and store content that is beneficial to protagonists and critics of antagonists, but also arouses sympathy from observers[9]. Social media can fulfill the rhetorical function of social action in terms of explaining the breadth of problems covered and action agendas; for example problems relating to actions, what is not part of actions, and certain groups whose behavior wants to be changed by actions[10].Some studies that have explained the function of media social in mobilizing action, such as how Twitter activists through the hashtag can mobilize the participants of the protest in real life[4]\&[11].

Hashtag is a "sign" or "tag" that starts with a hash symbol (\#), hashtag is a keyword for information on a tweet and can help in the process of finding information. Through the use of hashtags, a tweet can be accessed by anyone even if that person is not a Twitter user, so someone who produces tweets for certain purposes can target a broad audience[12].This research was conducted toreveal how online activists in Indonesia mobilize the masses through the use of hashtags on Twitter.

\section{Research Method}

This study is a quantitative and qualitative content analysis. Research with a mixed methods approach involves the collection of numerical information and text information so that the final database represents quantitative and qualitative information. Researchers make interpretations of statistical results, or they interpret themes or patterns that emerge from the data[13].

The hashtag data were processedwith Drone Emprit Academic (DEA),a big data system that curates and analyzes conversations that occur between Twitter users[14].The data were processed using keywords "Westpapua, Papua" for the Wamena riot case, and "\#HidupMahasiswa" for the demonstration of students against the bill, that happenedin the period September 23-25, 2019.

Qualitative analysis was then carried out on the ten most frequently used hashtags by activists via Twitter, to find out the most popular themes used to move the masses. Samples choosen have represented more than $80 \%$ of hashtag used from each protest.Xiong, Cho and 
Boatwright [11] used thematic analysis to find out the theme of hashtags used by activists on Twitter.

Table 1. Thematic analysis based on Xiong, Cho and Boatwright

\begin{tabular}{lll}
\hline No & Themes & Description \\
\hline 1 & $\begin{array}{l}\text { Linkages directly and } \\
\text { indirectly with protests }\end{array}$ & $\begin{array}{l}\text { The hashtag is directly related to the movement or } \\
\text { reflects conversations related to action }\end{array}$ \\
\hline 2 & $\begin{array}{l}\text { References to protest } \\
\text { motivations }\end{array}$ & $\begin{array}{l}\text { Hashtag that identifies the main problem that stands } \\
\text { out for action }\end{array}$ \\
\hline 3 & $\begin{array}{l}\text { Orientation to } \\
\text { expected actions }\end{array}$ & $\begin{array}{l}\text { Hashtags that promote certain actions that should be } \\
\text { taken by the relevant public }\end{array}$ \\
\hline 4 & $\begin{array}{l}\text { Specific events (single } \\
\text { or repetitive) }\end{array}$ & $\begin{array}{l}\text { Make use of hashtags that are commonly used to } \\
\text { insert topics related to movement }\end{array}$ \\
\hline 5 & References to victims & $\begin{array}{l}\text { Hashtags widely discussed those who were most } \\
\text { affected by the action }\end{array}$ \\
\hline 6 & $\begin{array}{l}\text { Mentioning the role of } \\
\text { activists }\end{array}$ & $\begin{array}{l}\text { Hashtag that discusses the role of certain activists in } \\
\text { the movement }\end{array}$ \\
\hline
\end{tabular}

\section{Results And Discussion}

\subsection{Wamena Riot Twitter Conversation}

There are 23,931 conversations on Twitter consisting of 1,745 tweets, 340 replies and 21,846 retweets that talk about the riots that occurred in Wamena. The riots that occurred in Wamena resulted in 94 different hashtags used in 13,324 Twitter conversations. This indicates that there are 10,607 tweets that do not contain any hashtags.

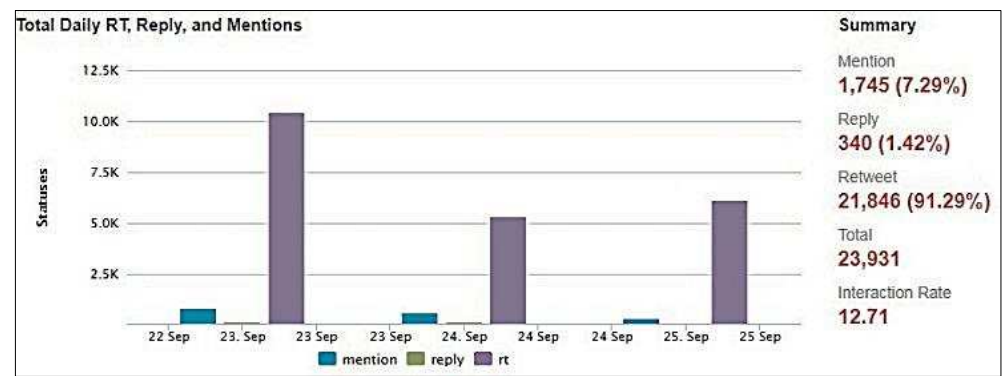

Fig.1.Conversation data about Wamena Riot

Source:DEA, 2019

Table 2. The ten most used hashtagsin Wamena Riots

\begin{tabular}{llcc}
\hline No & Hashtags & Occurences & \% Total \\
\hline 1 & \#WestPapua & 5,054 & 38 \\
\hline 2 & \#UNGA & 1,540 & 49 \\
\hline 3 & \#Indonesia & 1,046 & 57 \\
\hline 4 & \#FreeWestPapua & 878 & 64 \\
\hline 5 & \#Papua & 851 & 70 \\
\hline 6 & \#Wamena & 427 & 73 \\
\hline 7 & \#WestPapuaUprising & 345 & 76 \\
\hline 8 & \#Jayapura & 253 & 78 \\
\hline
\end{tabular}




\begin{tabular}{llcc}
\hline No & Hashtags & Occurences & \% Total \\
\hline 9 & \#Jakarta & 188 & 79 \\
\hline 10 & \#AfrikaForWestPapua & 186 & 80 \\
\hline- & Others & 2,556 & 100 \\
\hline
\end{tabular}

\section{a) Linkages directly and indirectly with protests}

The use of hashtags(3) \#Indonesia, (5) \#Papua, (6) \#Wamena included in the theme that is directly related to the protest movement. Activists use these words as a repetition which shows that protests took place in the city of Wamena, Papua Province, Indonesia.

The Indonesian govt has again blocked internet access in \#Wamena, as it did across Papua last month when a wave of large protests \& rioting spread through the region, leaving at least 10 people dead.Story:https://rnz.co.nz/international/pacific-news/399477/at-least-20-dead-in-latestwest-papua-violence via @RNZPacific \#WestPapua \#Papua \#Indonesia (Langeberg V, @v_langeberg, Sep. 24, 2019).

The hashtags of (8) \#Jayapura and (9) \#Jakarta are also included in the theme that indirectly related to the action in Wamena. Through the use of those hashtags, online activists pointed out there were other movements that might be related. There were issues that arise related to the termination of internet signals conducted by the Indonesian government to prevent the spread of hoax through social media. In addition, there was a protest that took place in Jakarta on September 25, 2019, one of which was the militarization of the West Papua case.

\section{b) Orientation to expected actions}

Activists used hashtags to promote specific actions to the public to advocate for social change. The hashtags used in this theme are (1) \#WestPapua, (2) \#UNGA, (4) \#FreeWestPapua, (7) \#WestPapuaUprising, and (10) \#AfrikaforWestPapua. Online activists in the Wamena riots used the most hashtags included in this theme in building social movements on Twitter.

In the tweet below, the use of hashtag \#WestPapua was used by activists to advocate foreign media and organizations to publicize and intervene the riots that occurred in Wamena. Important to note is the location of Wamena City, which is geographically located in Jayawijaya Regency, Papua Province. So in fact, it is not the right thing to say that Wamena is in West Papua Province[15].Another thing to note, West Papua is the preferred term for those who want to separate from Indonesia in order to form their own country.

English-language media yet to report widely on violence in \#WestPapua today. Students reportedly injured in Jayapura and Wamena. @reuters: Police spokesman said situation "is being handled by police and the military so that this does not spread wider" (Lopez B,@belle_lopez, Sep.23, 2019).

The use hashtag \#WestPapua in the riots that occurred in Wamena described that activists wanted to generalize events that occurred throughout Papua as actions that could support arguments on the issue of the release of the territory of West Papua from Indonesia.There were also phenomenon of the inaccurate dissemination of information from online activists to the public. It was said that the Wamena riots as a means of Indonesian to kill West Papuans who wanted independence,other tweets also narrated the Wamena riot as a result of local 
residents being attacked. Those two information conveyed messages as if the Wamena action attacked local residents, even though the facts showed that the majority of victims were migrants, not native Papuans[16].

\subsection{Student Protests Twitter Conversation}

Related to student protests rejecting the bill, the conversation that took place on Twitter resulted in 48,248 tweets, 6,908 replies and 803,157 retweets. During the three-day period, Twitter users produced 95 hashtags that being used 1,426,506 times. The number of hashtag usage that exceeds the total tweet that occurs shows that Twitter users often use two or more hashtags simultaneously.

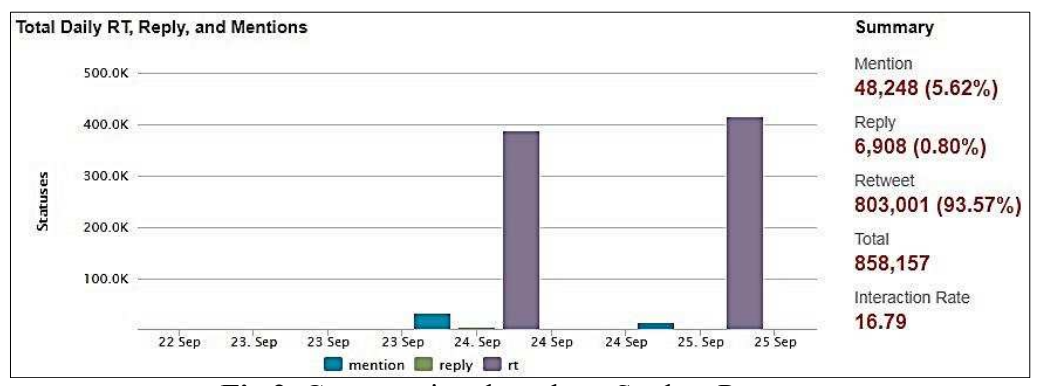

Fig.2. Conversation data about Student Protests Source:DEA, 2019

Table3. The ten most used hashtagsin Student Protests

\begin{tabular}{llcc}
\hline No & Hashtags & Occurences & \% Total \\
\hline 1 & \#HidupMahasiswa (\#GoStudents) & 827.874 & 58 \\
\hline 2 & \#TolakRUUKUHP (\#RejectTheCriminalCodeBill) & 116.020 & 66 \\
\hline 3 & \#HIDUPRAKYATINDONESIA(\#GloryIndonesian) & 76.135 & 72 \\
\hline 4 & \#MahasiswaBergerak (\#StudentsMove) & 63.021 & 76 \\
\hline 5 & \#MosiTidakPercaya (\#NoConfidenceMotion) & 37.950 & 79 \\
\hline 6 & \#TolakRevisiUUKPK (\#RejectTheCorruptionBill) & 26.541 & 80 \\
\hline 7 & \#ILCKontroversiRKUHP (\#ILCTheBillControvercy) & 24.658 & 82 \\
\hline 8 & \#TrisaktiTurunLagi (\#TrisaktiMoveAgain) & 23.937 & 84 \\
\hline 9 & \#STMmelawan (\#HighSchoolersOppose) & 16.316 & 85 \\
\hline 10 & \#AyoSemuaBergerak(\#LetsMoveTogether) & 15.670 & 86 \\
\hline- & Others & 198.384 & 100 \\
\hline
\end{tabular}

\section{a) Linkages directly and indirectly with protests}

Activists used the hashtag (2) \#RejectTheCriminalCodeBill and (6) \#RejectTheCorruptionBill in accordance with the actual purpose of the action.Students as representatives of the Indonesian, opposed the bill proposed by DPR. Students communicate about the purpose of the protest through those hashtags.

("There are only two reasons for the discrepancy; ignorance or it's subtle language is "foolishness" and there might behidden interests) - Chairman of BEM UGM. Short, solid, clear, and savage,also 
that smirk. I love you dude :) \#GoStudents \#GloryIndonesian \#RejectTheCriminalCodeBill (Rizka, @ Rizka_pr, Sep. 25, 2019).

\section{b) References to protest motivations}

A motivational themed hashtag was found for the action, namely (5) \#NoConfidenceMotion. The vote of no confidence has the actual meaning of a statement of distrust from the DPR towards the government or President. Although the notion of the phrase was irrelevant to actual conditions, activists using the term express distrust of the DPR. The ulteriormotive ofthe students to protest because they saw many conflict of interests in the drafting of the Criminal Code Bill.

Chairman of BEM UI Manik Marganamahendra: Many wild assumptions which circulate that our actions are ridden, yes indeed our actions are ridden, but we are ridden by the interests of the people! You're a Champion Manik !!! \#GoStudents \#NoConfidenceMotion \#RejectTheCriminalCodeBill (Individu Merdeka@IndivMerdeka, Sep. 24, 2019).

\section{c) Specific events (single or repetitive)}

There was also a hashtag with an event-specific theme, (7) \#ILCTheBillControvercy. On September 25, 2019, the student protester representatives, were invited to a television program discussing the controversy of the Criminal Code Bill. Also present was the Minister of Law and Human Rights Yasonna Laoly, who at that time criticized the arguments of the students.He assumed that the students did not fully understand the contents of the Criminal Code Bill. The criticism addressed to the students was later answered by Haris Azhar, a human rights activist, who defended the students.He stated that the problem in protesting the bill was the lack of trust from the public toDPR.

Big respect forbro@haris_azhar in \#ILCTheBillControversy you are the real MVP. His full emotional statement got me goose bump when $i$ watched it. And he become a lantern that keeps the fire for the younger generations at ILC who throughout the event want to be extinguished by hurricane \#GoStudents (txtdariku!, @Versi_Ku, Sep. 25, 2019).

\section{d) Mentioning the role of activists}

The hashtag as the trending topic, namely (1) \#GoStudents, can be categorized as the theme of the mention of the role of activists or activist mentions. This hashtag indicates that the protest was initiated and carried out by students. Students coordinate to mobilize the masses on a national scale through Twitter. Other popular hashtags that can be categorized in this theme include (4) \#StudentsMove, (3) \#GloryIndonesian, (8) \#TrisaktiMoveAgain, (9) \#HighSchoolersOppose and (10) \#LetsMoveTogether.

No matter which campus you are from, your alma mater. When we take to the streets, we become one big family. \#GoStudents \#TrisaktiMoveAgain (Kanat 20, @Kanat201, September 25, 2019).

Through conversation using hashtag\#TrisaktiMoveAgain, activists want to show the overall support to the protests because the students of the Trisakti University reportedly never again took to the streets to conduct protests or demonstrations during the last ten years. Activists also added the hashtag \#LetsMoveTogether which showed the support of the whole community to students who took action to the streets. In the end, the student movement was 
also followed by the younger generation, they were high schooler students. Through the hashtag \#HighSchoolersOppose, students who are specifically High School Technical Students, mobilized via Twitter to launch a protest.

\subsection{Discussion}

Hashtag on Twitter can serve as a label to identify the flow of messages that are relevant to the topic so that it can create a "conversation" between users[17].The use of hashtags on Twitter has a dual role, as a content tag as well as a symbol of membership in a community[18].Hashtags used by activists can predict their social relationships and also useful in predicting the popularity of these hashtags in the future[19].

Table 4. Thematic analysis summary

\begin{tabular}{|c|c|c|c|}
\hline No & Hashtag Themes & Wamena Riots & Student Protests \\
\hline 1 & $\begin{array}{l}\text { Linkages directly and indirectly } \\
\text { with protests }\end{array}$ & $\begin{array}{l}\text { \#Indonesia, \#Papua, } \\
\text { \#Wamena, \#Jayapura, } \\
\text { \#Jakarta }(\mathrm{n}=20,75 \%)\end{array}$ & $\begin{array}{l}\text { \#RejectTheCriminalCodeBill, } \\
\text { \#RejectTheCorruptionBill } \\
(\mathrm{n}=9,99 \%)\end{array}$ \\
\hline 2 & References to protest motivations & - & $\begin{array}{l}\text { \#NoConfidenceMotion } \\
(\mathrm{n}=2,66 \%)\end{array}$ \\
\hline 3 & Orientation to expected actions & $\begin{array}{l}\text { \#Westpapua, \#UNGA, } \\
\text { \#FreeWestPapua, } \\
\text { \#WestPapuaUprising, } \\
\text { \#AfrikaforWestPapua } \\
(\mathrm{n}=60,06 \%)\end{array}$ & - \\
\hline 4 & $\begin{array}{l}\text { Specific events } \\
\text { (repetitive or single) }\end{array}$ & - & $\begin{array}{l}\text { \#ILCTheBill Controvercy } \\
(\mathrm{n}=1,73 \%)\end{array}$ \\
\hline 5 & References to victims & - & 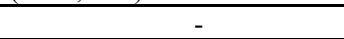 \\
\hline 6 & Mentioning the role of activists & - & $\begin{array}{l}\text { \#GoStudents,\#StudentsMove, } \\
\text { \#GloryIndonesian, } \\
\text { \#TrisaktiMoveAgain, } \\
\text { \#HighSchoolersOppose, } \\
\text { \#LetsMoveTogether } \\
(\mathrm{n}=71,71 \%)\end{array}$ \\
\hline
\end{tabular}

According to Romero, Meeder and Kleinberg, the controversial political hashtag is more persistent. If Twitter users retweet or reply to a message, it has a tremendous marginal effect. This is evidence of the sociological principle of "complex contagion", which means that repeated exposure to an idea is essential when it is in some way controversial or likely to be contentious [20].

\section{Conclusions}

There were differences in the use and theme of the hashtag for the two actions that occurred. Wamena riot activists mostly usedhashtags that promote certain actions that the relevant public should decide, which represented $60.06 \%$ of all conversations on Twitter about these events. While student protest activists highlighted the hashtag that discusses the identity or the role of the activists which represented $71.71 \%$ of the total hashtag used.This research was only limited to discussing the use and analysis of themes on hashtags used by activists. Further research can discuss other aspects relating to the hashtag, for example by the use of photos, videos or information links by activists in using Twitter as a tool to disseminate 
information and mobilize the masses. Research can also compare actions between Indonesia and abroad, or other social events so that they can gain a broader insight into hashtag activism through social media.

\section{References}

[1] L. C. Hutabarat, "Belasan Mahasiswa Papua Minta Maaf soal Rusuh Wamena," CNNIndonesia.com. $\quad$ https://www.cnnindonesia.com/nasional/20191004162800-32436830/belasan-mahasiswa-papua-minta-maaf-soal-rusuh-wamena (accessed Dec. 07, 2019).

[2] A. Ramadhan and I. Rastika, "Temuan dan Desakan Komnas HAM untuk Kerusuhan di Wamena,” Kompas.com. https://bandung.kompas.com/read/2019/10/01/06591851/ temuan-dandesakan-komnas-ham-untuk-kerusuhan-di-wamena?page=all (accessed Dec. 07, 2019).

[3] M. Hendartyo and E. Kurniawati, "Mahasiswa Demo di Beberapa Daerah, Lihat Tuntutannya," Tempo.com. https://nasional.tempo.co/read/1251569/mahasiswa-demo-di-beberapa-daerahlihat-tuntutannya/full\&view=ok (accessed Dec. 07, 2019).

[4] J. Penney and C. Dadas, "(Re)Tweeting in the service of protest: Digital composition and circulation in the Occupy Wall Street movement," New Media Soc., vol. 16, no. 1, pp. 74-90, 2014, doi: 10.1177/1461444813479593.

[5] M. T. Bastos, R. Recuero, and G. Zago, "Taking tweets to the streets: A spatial analysis of the Vinegar Protests in Brazil," First Monday, vol. 19, no. 3, 2014. https://firstmonday.org/article/view/5227/3843 (accessed Dec. 07, 2019).

[6] R. Recuero, G. Zago, M. T. Bastos, and R. Araújo, "Hashtags functions in the protests across brazil," SAGE Open, vol. 5, no. 2, pp. 1-14, 2015, doi: 10.1177/2158244015586000.

[7] R. Kuo, "Racial justice activist hashtags: Counterpublics and discourse circulation," New Media Soc., vol. 20, no. 2, pp. 495-514, 2018, doi: 10.1177/1461444816663485.

[8] Stephen W. Littlejohn, K. A. Foss, and J. G. Oetzel, THEORIES OF HUMAN COMMUNICATION Eleventh Edition, vol. 53, no. 95. 2012.

[9] M. Chan, "Media Use and the Social Identity Model of Collective Action: Examining the Roles of Online Alternative News and Social Media News," Journal. Mass Commun. Q., vol. 94, no. 3, pp. 663-681, 2017, doi: 10.1177/1077699016638837.

[10] D. J. Wilkins, A. G. Livingstone, and M. Levine, "Whose tweets? The rhetorical functions of social media use in developing the Black Lives Matter movement," Br. J. Soc. Psychol., vol. 58, no. 4, pp. 786-805, 2019, doi: 10.1111/bjso.12318.

[11] Y. Xiong, M. Cho, and B. Boatwright, "Hashtag activism and message frames among social movement organizations: Semantic network analysis and thematic analysis of Twitter during the \#MeToo movement," Public Relat. Rev., vol. 45, no. 1, pp. 10-23, 2019, doi: 10.1016/j.pubrev.2018.10.014.

[12] T. A. Small, "What the hashtag?: A content analysis of Canadian politics on Twitter," Inf. Commun. Soc., vol. 14, no. 6, pp. 872-895, 2011, doi: 10.1080/1369118X.2011.554572.

[13] J. W. Creswell, Research design : qualitative, quantitative, and mixed methods approaches. Thousand Oaks, CA: Sage Publications, 2014.

[14] I. Fahmi, "Drone Emprit Konsep dan Teknologi," Slideshare.net. https://www.slideshare.net/IsmailFahmi3/drone-emprit-konsep-dan-teknologi (accessed Dec. 08, 2019).

[15] The Government of West Papua, "Kabupaten Kota di Provinsi Papua Barat," Pemerintah.net. https://pemerintah.net/kabupaten-kota-di-provinsi-papua-barat/ (accessed Dec. 15, 2019).

[16] J. R. P. and A. Gabrillin, "Daftar Nama 31 Korban Tewas Kerusuhan Wamena," kompas.com. https://regional.kompas.com/read/2019/09/26/15401191/daftar-nama-31-korban-tewaskerusuhan-wamena (accessed Dec. 21, 2019).

[17] J. Huang, K. M. Thornton, and E. N. Efthimiadis, "Conversational tagging in Twitter," HT'10 Proc. 21st ACM Conf. Hypertext Hypermedia, pp. 173-177, 2010, doi: 
$10.1145 / 1810617.1810647$.

[18] L. Yang, T. Sun, M. Zhang and Q. Mei, "We know what@you \#tag: does the dual role affect hashtag adoption?” In Proc. Of WWW'12, pp. 261-270, 2012.

[19] D. M. Romero, C. Tan, and J. Ugander, "On the interplay between social and topical structure," Proc. 7th Int. Conf. Weblogs Soc. Media, ICWSM 2013, pp. 516-525, 2013.

[20] D. M. Romero, B. Meeder, and J. Kleinberg, "Differences in the mechanics of information diffusion across topics: Idioms, political hashtags, and complex contagion on twitter," Proc. 20th Int. Conf. World Wide Web, WWW 2011, pp. 695-704, 2011, doi: $10.1145 / 1963405.1963503$. 